\title{
Recent Developments in Understanding Spirituality as Exemplified by the Concept of Self-Transcendence
}

\author{
ANDRZEJ K. JASTRZĘBSKI \\ Saint Paul University, Ottawa, Canada \\ ajastrzebski@ustpaul.ca, ORCID: 0000-0003-2637-7706
}

\begin{abstract}
The recent history of science has witnessed many shifts of paradigms. One of the major changes has been observed in the shift of spirituality, transforming from a traditional faith-based notion to a more secular or postmodern one. These changes are confusing for many modern people as they are not able to follow these rapid developments. This article is an attempt at providing a conceptual framework to understand the changes that the notion of spirituality has undergone using the concept of self-transcendence and its two major dimensions: vertical and horizontal. This model will serve to evaluate different ways of defining spirituality in both theology and the social sciences and to indicate the provenience of their roots in both disciplines. In conclusion, self-transcendence will be compared with the concept of self-actualization.
\end{abstract}

Keywords: spirituality, self-transcendence, vertical, horizontal, self-actualization

Both, in our society and in science, we have witnessed many major shifts in perspective. These changes can be traced all through the twentieth century until the present day. One of the most dynamic transformations has taken place in our understanding of spirituality. Although its origins are clearly religious in the Christian-Western-Catholic milieu, today, the notion of spirituality has crossed all former boundaries and has become nearly all-inclusive, thus compelling it to become vague and unreliable.

The classical, religion based notion of spirituality, which can be called a "hard version," refers one to a reality that transcends one's own self and one's own material world. In the modern, "soft versions" of spirituality, relating to a transcendent reality is not necessary; it is sometimes even considered politically incorrect. And yet the human capacity to self-transcend, generally meaning a conscious experience of going beyond oneself toward what one perceives as something of ultimate value, seems to be one of the major characteristics of the human being.

Indeed, contemporary research in humanities and social sciences shows that people who see themselves related to something greater than the self often feel happier and have a deeper sense of purpose in their lives. Generally speaking, we can 
say that the human spirit is the underlying dynamism of human self-transcendence, which intentionally directs itself naturally to what can be known and loved. This spirit is not designed to be enclosed in itself, but to go out into the world and to reach out to other persons. ${ }^{1}$

\section{The Conceptualization of Self-Transcendence}

To better understand what has happen with the contemporary notion of spirituality, we can use the concept of self-transcendence developed by Karol Wojtyła. In his most important philosophical work, The Acting Person, Wojtyła introduces self-transcendence as the essential expression of our spirituality, which he links to two other concepts: self-determination and conscience. Through self-transcendence, we experience a spiritual dynamism, which, by its nature is immaterial and we discover that we are capable of transcending both our psychic constitution as well as the limitations of our body. As a consequence, spirituality is the integrating principle of our lives and cannot be reduced to psychic or organic processes. ${ }^{2}$

Wojtyła's most original contribution in this context is to present two different dimensions of self-transcendence: horizontal and vertical. He sees vertical self-transcendence as that of the person who has chosen to confront their own existence with a point of reference that is to be found beyond their personal human limitations such as an entirely free and intentionally chosen self-dependence on the truth or God. Horizontal self-transcendence is an intentional act such as directing ourselves toward other persons or objects. ${ }^{3}$ Both forms of self-transcendence put together define spirituality in a very interesting way that will allow us to understand the shift in the notion of spirituality that has taken place recently. We propose to name the vertical self-transcendence "ontological" and the horizontal "moral" or "ethical" transcendence. This is a slight modification of Wojtyła's original thought, but it gives a clearer distinction of these two variants of self-transcendence.

When we conceive spirituality as reaching out to something beyond the human person, it becomes a very useful, two-dimensional concept. From a religious perspective, ontological self-transcendence means reaching out to God and searching to enter and sustain the relationship with God or, in more Christian terms, with the Holy Spirit. This dimension has in fact disappeared along the way through secularizing the concept of spirituality in modern social sciences. The ontological self-transcendence or, more precisely, the ontological dimension of self-transcendence, refers to

\footnotetext{
Helminiak, "Confounding the Divine," 171.

Wojtyła, The Acting Person, 170.

Wojtyła, The Acting Person, 160.
} 
the understanding of a spirituality that is sometimes called "substantial" meaning that it acknowledges the existence of supernatural reality. ${ }^{4}$

The ethical dimension of self-transcendence refers to the human capacity of reaching beyond oneself, through selflessness, and intentional sacrifice, thus overcoming one's weakness and egoist tendencies. For example, as humans, we can transcend our physiological constitution by continuing to write while living with persistent back pain; we are also capable of overcoming mental constrains such as depression, thus overcoming both our material and immaterial functioning. ${ }^{5}$ This can be exemplified by: acts of love, protection of human dignity and respect for human rights and freedom. ${ }^{6}$

To some extent, this dimension of self-transcendence can be related to the concept of "functional" spirituality, indicating the purpose that spirituality serves and not so much its nature. ${ }^{7}$ Certainly, both dimensions of self-transcendence are essential from a faith-based perspective. From a secular perspective, spirituality is seen from a more pragmatic vantage point where the horizontal/ethical aspect is more valued than any ontological motivation. ${ }^{8}$

In contemporary society, there is a strong tendency to self-realize or self-actualize, which opens the door to an entirely subjective understanding of spirituality without any reference to the concept of self-transcendence, not even to its horizontal dimension. Although so highly praised nowadays, self-awareness, as an important element of being human, may easily impair our capacity for self-transcendence which, according to Wojtyła, is crucial for one's self-fulfillment. ${ }^{9}$ For Frankl, self-actualization is a by-product of self-transcendence. ${ }^{10}$ Let us now characterize the vertical and horizontal forms of self-transcendence.

\section{Vertical or Ontological Self-Transcendence}

In theological terms self-transcendence is activated by the power of the Source of Being, where the finite being is drawn to God and invited to a deep relationship with Him. However, the power of self-transcendence does not originate in the human being. Its roots and its destination are Divine. ${ }^{11}$ We will distinguish two aspects

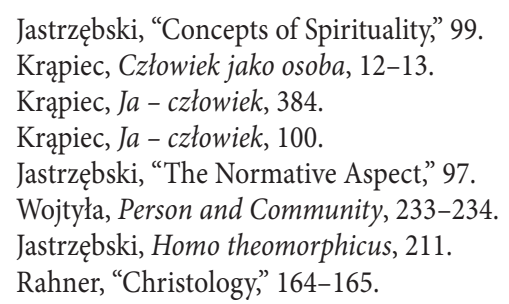


of the vertical self-transcendence: imago Dei and theosis; the first being a point of arrival or a goal and the second the process that leads to the accomplishment of the former.

\subsection{Imago Dei}

The concept of self-transcendence can be related to a core topic in theological anthropology which is the doctrine of the imago Dei. With its roots in Genesis 1:26-27, it states that the human being has been created in the image of God. According to one of the interpretations of this text, called functional, being God's image is related to the mission of stewarding the world. These ideas from the Bible and early Christian theology were researched by many prominent theologians such as Karl Rahner, Paul Tillich, Wolfhart Pannenberg, Karl Barth, Hans Urs von Balthasar, and Jürgen Moltmann. ${ }^{12}$ We will focus our attention here on Pannenberg's thought.

According to Wolfhart Pannenberg, the functional interpretation of God's image pertains to a more general theological topic of our mission in the universe. ${ }^{13}$ This mission is the fundamental dynamism of our being. We are called to go beyond what we are. ${ }^{14}$ The works of early Church Fathers pointed to the dynamic dimensions of the human being. Also, they argued about the distinction between image and likeness. Being God's image is understood as stemming directly from Creation and is expressed in rather static terms. On the other hand, likeness is presented as a dynamic process in which we are invited to progress and perfect ourselves in reference to God's image. This is the call for self-transcendence ${ }^{15}$. Its motivation is clearly divine.

We can understand being God's image as the design and likeness being the destiny (something to be attained) of every human being. Pannenberg tends to point towards the future and interpret the imago Dei as one's destiny (Bestimmung) or goal. ${ }^{16}$ His interpretation is eschatological: the fullness of creation in God's image remains located in the future, connected with the second coming of Jesus Christ, when Christians believe they will be sanctified at the end of time. According to Pannenberg, in order to reach the goal to which Christians are destined, individuals have to be raised above themselves, to be lifted above what they already are, ${ }^{17}$ and in this sense self-transcendence is a constant process that can be called deification.

\footnotetext{
12 Ladaria, Antropologia teologica, 147; Robinson, Understanding the 'Imago Dei.'

13 Wong, "Image of God," 59.

14 Van Huyssteen, Alone in the World?, 141.

15 Colagè, “The Human Being," 1007.

16 Shults, “Theology, Science, and Relationality," 816; Pannenberg, Systematic Theology, 180-181.

17 Wong, "Image of God," 51.
} 


\subsection{Theosis}

In Eastern Christianity, the process of deification (Greek: theosis, theopoiesis; Latin: deificatio) describes, a new state of the human person transformed by the Holy Spirit. This process leads the human person to come as closely as possible to illustrating the likeness to God (Greek: homoiosis theo) in their life. It does not mean that we become God, but that through God's grace, we participate as fully as possible in God's nature. ${ }^{18}$ From the vantage point of faith, this is the highest point of human self-transcendence.

God's image (eikon) is the dynamic foundation of self-transcendence as its point of arrival and the process of deification is its accomplishment over time. Thanks to the transforming presence of the Holy Spirit, the human person can progressively assimilate the blessed life of God and becomes God-like, which is also God's desire for the whole humanity. ${ }^{19}$

Deification is not a gift added to our nature. It is, however, an important element of transformed human nature, where it reflects its original model, having become a full image of the Triune God. Deification is an act of self-transcendence and transformation through which the human person not only surrenders to the redemptive work of Christ, but is actively involved in the discovery of their true destiny. ${ }^{20}$ In the Christian tradition, one speaks about the natural longing (desiderium naturale) for God that can only be fulfilled through God's grace. Ultimately, vertical self-transcendence can be called "the fullest humanization of the human being." ${ }^{21}$

Deification or vertical self-transcendence is realized through the sacraments, where the baptized person dies with Christ in order to be born into his resurrected life. Through baptism, Christians receive their new existence, through confirmation the gift of the Spirit, and through the Eucharist the very life of God. Deification is caused by the power of the Holy Spirit through the sacraments of the Church and is demonstrated in the life of a believer through spiritual practices such as prayer, fasting, and almsgiving. ${ }^{22}$

\section{Between Vertical and Horizontal Self-Transcendence}

It has to be noted that from the vantage point of faith, both dimensions of self-transcendence are interrelated. Only in the modern secular understanding of spiritual-

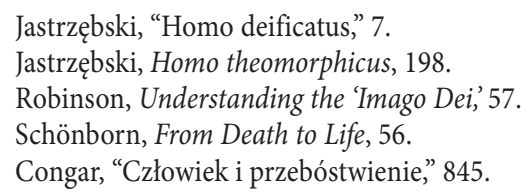


ity, the horizontal self-transcendence can be seen in isolation, both with or without an explicit reference to Transcendence that at times is not associated with God. Nonetheless, there is one dimension of self-transcendence that can be seen as a mediator between both vertical and horizontal transcendence: our conscience.

As humans, we are interiorly compelled to look for truth, which affirms our transcendent nature. Through our minds, we come to an in-depth knowledge of the truth, although this truth does not need to be religiously impregnated. It is clear that for believers, this truth is God, but for secular social sciences, it is some kind of external instance that helps us judge our actions ethically. Self-transcendence in this context reveals itself in the cognitive effort of the human mind directed towards the truth. The human mind subordinates naturally to truth, because, metaphorically speaking, the truth is its light. In the human conscience, the dependency of mind on truth is revealed. This is another dimension of self-transcendence that is both vertical and horizontal. Vertical, because it transcends the individual human mind, horizontal, because it does not assume any supernatural reality. ${ }^{23}$

In human nature we discover two inexplicable phenomena: awareness and responsibility. Both of them can be experienced as the voice of conscience, of a clear, moral self-evaluation. This moral intuition can err, but it does not change the fact that we perceive it. When we enter into dialogue with our conscience, we discover the existence of a Superior Power, or experience transcendence. ${ }^{24}$

\section{Horizontal or Ethical Self-Transcendence}

The horizontal dimension of self-transcendence can be found in many modern definitions of spirituality that originate in both religious and secular context and thus are a natural bridge between these different ways of understanding spirituality.

\subsection{Horizontal Self-Transcendence from a Religious Perspective}

Some theologians attempt to define spirituality in terms of horizontal self-transcendence in order to create a context for dialog with social sciences. For instance, David Perrin says that "spirituality, as an innate human characteristic, involves the capacity for self-transcendence: being meaningfully involved in, and personally committed to, the world beyond an individual's personal boundaries." ${ }^{25}$ Christian mystics often name the transcendent values towards which the movement of self-transcending

\footnotetext{
Wojtyła, The Acting Person, 159.

Frankl, Man's Search, 64.

Perrin, Studying Christian Spirituality, 20.
} 
may direct itself such as justice, love, reconciliation, and peace. In fact, such values are shared by many religious traditions and also by people that describe themselves as spiritual but non-religious. The major difference from the Christian perspective is that the foundation of self-transcending energy in the human being is the transforming power of the Holy Spirit. ${ }^{26}$

Sandra Schneiders relates her understanding of spirituality to self-transcendence as a conscious experience of going beyond oneself toward what one perceives as something of ultimate value. ${ }^{27}$ Since here, we have no reference to any supernatural reality, such understanding of spirituality can be accepted by many social scientists.

Bernard Lonergan defines self-transcendence as an authentic existence. Having an authentic existence means having reached one's full human potential, including these four dimensions of spirituality: being attentive, intelligent, reasonable, and responsible. These constitute the transcendental and formal principles of development involved in the structure of our existence and, as such, can lead to self-transcendence becoming a normative principle. ${ }^{28}$ This kind of presentation of spirituality or self-transcendence remains very close to their secular counterparts.

\subsection{Horizontal Self-Transcendence from a Non-Religious Perspective}

Horizontal or ethical self-transcendence has become an essential part of existential thought. It took the form of the authentic self; i.e., being independent from social and political frames such as totalitarianism and conformism which take away our dignity and freedom ${ }^{29}$. Authentic being in this regard signifies a life faithful to one's chosen values. We can self-transcend and become a better and unique person, which again indicates that self-transcendence has an ethical character.

Self-transcendence can also be seen in the human capacity to act against the constraints of one's body and psyche. Many times, we discover that we are capable of transcending both our psyche and body. ${ }^{30}$ It can be attained and revealed through self-mastery, but also through employing self-realization. To be human is to be open to the world and not closed within one's own subjectivity. Self-awareness may be expressed by turning towards oneself, but the capacity for self-transcendence proves the ontological inclination of the human person to move outside of themselves, towards reality. In this way, self-fulfillment remains closely associated with self-transcendence, ${ }^{31}$ which cannot be grasped without linking it to the structures of the person, those of self-governance and self-possession. Only against the background of

\footnotetext{
Perrin, Studying Christian Spirituality, 133-134.

Schneiders, "Spirituality in the Academy," 684.

Lonergan, Insight, 53.

Van Deurzen, Everyday Mysteries, 343.

Wojtyła, The Acting Person, 170.

Wojtyła, Person and Community, 233-234.
} 
these structures can we appropriately interpret the dynamism of self-determination where self-transcendence has its roots. ${ }^{32}$

Along the same lines, Victor Frankl states that we only begin to show our ability to self-transcend, when we take control over the psychophysical (body and psyche). Only in this context can we completely manifest who we can be, because our dignity is inseparably connected with our spiritual or noogenic dimension. Frankl states that sickness cannot decrease our very existence, yet, it can "cover it up." Since the spiritual person or the very core of our being has to use their organism to communicate with the world, their handicap will result in a certain inertia that will create a new context for self-transcendence. As humans capable of self-transcendence, we always remain open to a world filled with other persons who we can meet and new meanings that we can fulfill. ${ }^{33}$

According to Frankl, to self-transcend means to be directed towards something or someone through work, a loving relationship or mission, to which we intentionally sacrifice ourselves. Outside of ourselves, we discover the world of values, and by realizing their potential, we perform acts of self-transcendence. Frankl definitely distinguishes acts of self-transcendence, which focus the self on objective values, from the process of self-actualization, which is guided more by the principle of pleasure associated with actualizing our potentialities. He points out that self-actualization should be only a side effect of self-transcendence. ${ }^{34}$ This is an important point for understanding and evaluating the modern concepts of spirituality presented in social sciences.

\section{Conclusion: Self-Actualization Versus Self-Transcendence}

It is obvious that in our contemporary culture there is a tension between the secular and religious dimensions of human life, which is demonstrated clearly in varying notions of spirituality. Analyzing the concept of self-transcendence helps us to understand it more systematically. The common point of interest for both secular humanism and religion can be ethical self-transcendence. It can be a platform of dialog for both.

Apart from the tension between religious and humanist spirituality exemplified on vertical and horizontal dimension of self-transcendence, there is also another one: between ethical self-transcendence and self-actualization. This is well-illustrated in various psychological arguments between existential and humanist schools. In

Wojtyła, The Acting Person, 159.

Frankl, The Will to Meaning, 113.

Jastrzębski, Homo theomorphicus, 211. 
both cases, one underlines a desire to make the most of their lives. On the one hand, people seek to realize all their potential and accumulate experience, on the other, some understand that a greater sense of who they are does not come from the dynamism of self-actualization promoted by our society, but rather from their innermost motivation, their desire to seek and fulfill the purpose of life. This purpose does not seem to be self-actualization, but rather transcending, reaching beyond ourselves in order to achieve discovered objective goals and values.

For existential psychotherapy, self-transcendence is the very essence of being human. As humans, we are capable of defying biological, psychic and social determinisms. We can act contrary to our impulsive tendencies as well as go beyond the boundaries of our pathological and social conditions. It is this phenomenon of freedom which is the essence of spirituality discernable as self-transcendence. In any concrete existential situation, we are able to appeal simultaneously to our freedom and to our sense of responsibility. ${ }^{35}$ Unlike motivation based on meeting needs, motivation associated with the search for meaning through the choice of values is characterized by attraction rather than compulsion.

We can define ourselves by reference to the objective world of values and meaning. Self-transcendence emerges from the convergence of "transcendence" and "spirit" as a human capacity to rise above the necessities of nature. Even if we do not reach the summit of our human potentials, we always remain essentially able of transcending natural necessity, which defies strict determinism. There will always be challenges that go beyond our human abilities, yet we regularly exceed our limits by making appropriate use of our freedom. ${ }^{36}$

The dynamism of self-transcendence ultimately decides the outcome of the situations we encounter in life. Speaking from a more existential perspective, we are able to face the task of adopting fate and integrating it into our own destiny. We do not need to get lost in any life situation so long as we can establish a distance (self-transcendence) between ourselves and this particular situation, which enables us to take the appropriate attitude towards it: to agree to it or oppose it. Thanks to this self-distancing capacity, freedom can be reinforced in us, and only thanks to this freedom can we make decisions against natural inclination or the atrocity of a situation. ${ }^{37}$

According to Frankl, we can actualize our capacity of self-transcendence by creating something new, or contributing something positive to this world, by experiencing goodness, truth, or the beauty coming from nature or from culture, and by encountering someone and offering this person our love. However, the highest manifestation of ethical self-transcendence may be realized by those deprived of these opportunities. Through their attitudes, they are able to transcend themselves

\footnotetext{
35 Frankl, Homo patiens, 206.

36 Frankl, Homo patiens, 241.

37 Jastrzębski, Homo theomorphicus, 123.
} 
and transform their suffering into achievement, even if it means transforming their suffering into an act of heroism, probably the highest level of self-transcendence or spirituality attainable. ${ }^{38}$

In the modern most functional and soft definitions of spirituality, there is no room for self-transcendence, not even for its ethical dimension. The soft functional definitions are purely pragmatic in nature such as understanding spirituality as simply being at peace with oneself. Sometimes it refers to an ideology or a lifestyle. It can also include inner strength, inner harmony, well-being or contentment, gratefulness and life satisfaction, as well as low levels of conflict in life. Such a way of understanding spirituality is very difficult to distinguish from the description of mental well-being. ${ }^{39}$ The humanistic trends towards self-actualization were criticized from the religious grounds and defined as a "selfist" psychology or culture, with its hostility towards discipline, obedience, and deferment of gratification, ${ }^{40}$ egoistic attitudes, and, in our terms, impairment of self-transcendence.

More existentially inclined thinkers see a great potential in promoting the concept of self-transcendence related to spirituality:

Spiritual development is the process of growing the intrinsic human capacity for self-transcendence, in which the self is embedded in something greater than the self, including the sacred. It is the developmental "engine" that propels the search for connectedness, meaning, purpose and contribution. It is shaped both within and outside of religious traditions, beliefs and practices. ${ }^{41}$

Self-transcendence understood as an integrating force of the human life, can redirect modern people toward chosen values, tradition, and life's purpose. In the contemporary world, the major threat to self-transcendence is the process of dehumanization, which causes the loss of the human self because of excessive individualism that in turn leads to alienation and despair. Promoting the idea of self-transcendence could become an antidote to the "empty or false self" emerging in the context of postmodern society as an illusion of egocentric human desires. ${ }^{42}$ Unfortunately, for many people, this false self is and remains the basis of life and they are not able to achieve their most profound desires and find the meaning of life. In this context, promoting the idea of self-transcendence can be very helpful, even crucial for the well-being of our contemporary society, because it has capacity to lead to an understanding of spirituality in social sciences that is not totally divorced (or at odds) from its religious roots.

Frankl, The Will to Meaning, 60.

Jastrzębski, "The Challenging Task," 11-12.

See: Vitz, Psychology as Religion, 62.

Benson - Roehlkepartain - Rude, "Spiritual Development," 205-206.

Ryan, Four Steps to Spiritual Freedom, 19. 


\section{Bibliography}

Benson, P.L. - Roehlkepartain, E.C. - Rude, S.P., "Spiritual Development in Childhood and Adolescence: Toward a Field of Inquiry," Applied Developmental Science 7 (2003) 204-213.

Colagè, I., "The Human Being Shaping and Transcending Itself: Written Language, Brain, and Culture," Zygon 50 (2015) 1002-1021.

Congar, Y., "Człowiek i przebóstwienie w teologii prawosławnej," Znak 20/7-8 (1968) 841-865.

Frankl, V.E., Homo patiens (Warszawa: Pax 1976).

Frankl, V.E., The Will to Meaning. Foundations and Applications of Logotherapy (New York: Meridian 1988).

Frankl, V.E., Man's Search for Ultimate Meaning (New York: Basic Books 2000).

Helminiak, D.A., "Confounding the Divine and the Spiritual: Challenges to a Psychology of Spirituality," Pastoral Psychology 57 (2008) 161-182.

Jastrzębski, A., “Homo deificatus,” Wrocławski Przegląd Teologiczny 23/1 (2015) 7-18.

Jastrzębski, A., "Concepts of Spirituality at Universities of Today," Roczniki Teologiczne 66/5 (2019) 99-113.

Jastrzębski, A., Homo theomorphicus et theophoricus. A Receptive-Responsive Theory of Spirituality (Leuven - Paris - Bristol, CT: Peeters 2019).

Jastrzębski, A., "The Normative Aspect in the Contemporary Understanding of Spirituality," Wrocław Theological Review 28/2 (2020) 95-111.

Jastrzębski, A.K., "On Some Anthropological Foundations of Spirituality," Verbum Vitae 37/2 (2020) 381-390.

Jastrzębski, A.K., "The Challenging Task of Defining Spirituality”, Journal of Spirituality in Mental Health (2020) 1-19, https://doi.org/10.1080/19349637.2020.1858734.

Krąpiec, M.A., Ja - człowiek (Lublin: TN KUL 1986).

Krąpiec, M.A., Człowiek jako osoba (Lublin: PTTA 2005).

Ladaria, L.F., Antropologia teologica (Rome: Gregorian and Biblical Press 2011).

Lonergan, B.J.F., Insight. A study of Human Understanding (Collected works of Bernard Lonergan 3; Toronto: University of Toronto Press 1992).

Pannenberg, W., Systematic Theology (Edinburgh: Clark 1994) II.

Perrin, D.B., Studying Christian Spirituality (New York: Routledge 2007).

Rahner, K., "Christology within an Evolutionary View of the World," Theological Investigations (London: Darton, Longman \& Todd 1966) V, 157-192.

Robinson, D., Understanding the 'Imago Dei.'The Thought of Barth, von Balthasar and Moltman (Farnham: Ashgate 2011).

Ryan, T., Four Steps to Spiritual Freedom (New York: Paulist Press 2003).

Schneiders, S.M., "Spirituality in the Academy," Theological Studies 50 (1989) 676-697.

Schönborn, Ch., From Death to Life. The Christian Journey (San Francisco, CA: Igniatius Press 1995).

Shults, F.L., "Theology, Science, and Relationality: Interdisciplinary Reciprocity in the Work of Wolfhart Pannenberg," Zygon 36/4 (2001) 809-825.

Van Deurzen, E., Everyday Mysteries. A Handbook of Existential Psychotherapy (London - New York: Routledge 2009). 
Van Huyssteen, J.W., Alone in the World? Human Uniqueness in Science and Theology (Grand Rapids, MI: Eerdmans 2006).

Vitz, P.C., Psychology as Religion. The Cult of Self-Wroship (Grand Rapids, MI: Eerdmans 1977).

Wong, K.M., "Image of God as Both Fount and Destiny of Humanity: How Herderian is Pannenberg?" Scottish Journal of Theology 59/1 (2006) 45-63.

Wojtyła, K., The Acting Person (trans. A. Potocki) (Analecta Husserliana 10; Dordrecht - Boston, MA - London: Reidel 1979).

Wojtyła, K., Person and Community. Selected Essays (New York: Lang 1993). 